Vol. 3 | No. 1 | 2022 | Hal. 35-40

\title{
PENINGKATAN KESEJAHTERAAN EKONOMI MASYARAKAT DIMASA PANDEMI COVID-19 MELALUI EDUKASI PUPUK ORGANIK DAN TEKNOLOGI HIDROPONIK DALAM PERTANIAN ORGANIK
}

\author{
Efendi S Wirateruna*, Niko Dian Pramana, Tedi Cahyono, Diyah Ari Manisa, Risna \\ Faulia, Hanik Latifah, Asti Widya Asmarani \\ Fakultas Teknik, Universitas Islam Malang \\ *korespondensi email: efendi.s.wirateruna@unisma.ac.id
}

\begin{abstract}
ABSTRAK
Dengan adanya pandemi COVID-19 ini segala aktivitas masyarakat harus terbatasi. Pembatasan ini berdampak pada pekerjaan mereka. Akibat pandemi COVID-19 semakin hari jumlah penggagunggaran semakin meningkat. Sehingga masyarakat perlu mencari alternatif untuk menghasilkan pendapatan. Salah satunya yaitu dengan melakukan bercocok tanam, namun banyak dari masyarakat yang mengeluh karena tidak mempunyai lahan yang luas. Permasalah ini dapat disiasati dengan melakukan bercocok tanam menggunakan teknologi hidroponik karena teknologi hidroponik ini tidak membutuhkan lahan yang luas. Dengan permasalah tersebut, KSM Tematik Unisma 2021 melakukan kegiatan untuk bercocok tanam dengan teknologi hidroponik guna untuk dapat meningkatkan penghasilan masyarakat dimasa pandemi COVID-19. Dalam pemupukan teknologi hidroponik ini menggunakan pupuk organik cair supaya selalu menciptakan pangan yang sehat. Selama kegiatan pengabdian terdapat indikator keberhasilan yang diperoleh adalah pembuatan alat untuk pembuatan pupuk pupuk organik baik dalam bentuk cair maupun padat yang berasal dari sisa limbah rumah tangga, dan pembuatan media tanam Hidroponik dari pipa dengan lahan yang terbatas. Pembuatan hidroponik cukup efektif dan mudah dipraktikkan oleh masyarakat sekitar, sehingga dengan keterbatasan lahan masyarakat tetap mampu menanam tanaman organic seperti sayuran dengan bahan pupuk organik. Kegiatan pelatihan dan edukasi pembuatan hidroponik dihadiri beberapa perwakilan masyarakat sehingga mereka siap menjadi kader untuk pelatihan hidroponik kepada masyarakat lain. Hal ini akan membuat program edukasi hidroponik dapat berjalan dengan mandiri oleh masyarakat tersebut.
\end{abstract}

Kata Kunci: pandemi COVID-19; hidroponik; pertanian organik; pupuk organik

\section{PENDAHULUAN}

Pandemi COVID-19 ini masih melanda dunia termasuk Indonesia. COVID-19 memiliki sifat penularan yang sangat cepat sehingga segala aktivitas diluar rumah sangat dibatasi (Kurniasih, 2020; Perdamaian et al., 2020; Vivi Gorahe et al., 2021). Hal ini menyebabkan berbagai permasalahan salah satunya dari segi ekonomi. Salah satu desa yang terdampak akibat adanya COVID-19 yaitu Desa Wonoanti.

Desa Wonoanti merupakan salah satu desa yang terletak di Kecamatan Gandusari, Kabupaten Trenggalek, Jawa Timur, Indonesia. Desa ini tergolong desa yang maju dan cenderung homogen. Banyak potensi yang ada di Desa Wonoanti salah satunya adalah potensi dalam bidang kerajinan tangan dan bidang pertanian. 
Dalam bidang kerajinan tangan yang telah dihasilkan Desa Wonoanti ini sudah tembus pasar ekspor luar negeri, karena kerajinan yang di hasilkan memiliki kualitas dan desain yang baik. Negara yang sering membeli kerajinan tangan ini adalah Korea Selatan dan Brunei Darussalam. Kerajinan tangan yang telah dihasilkan seperti vas bunga, souvenir, meja, kursi, capil, tempat lampu, rantang makanan dan masih banyak lagi.

Dalam bidang pertanian di desa ini menjadi salah satu mata pencarian utama masyarakat, seperti petani jagung, petani padi, dan budidaya sayuran. Namun, sebagian besar penduduknya masih banyak menggunakan pupuk dan pestisida kimia secara berkepanjangan yang dapat merusak sifat fisik tanah. Saat ini tersedia pupuk organik yang efektif untuk produksi berbagai tanaman sayuran melalui metode hidroponik (Muhadiansyah et al., 2016). Oleh karena itu sebagian masyarakat berinisiatif untuk membentuk Gabungan Kelompok Tani (GAPOKTAN) yang digunakan sebagai wadah masyarakat untuk mengembangkan berbagai teknologi pertanian menggunakan bahan organik yang ada di lingkungan sekitar.

Pengembangan pertanian organik mulai digalakkan oleh Bupati Trenggalek melalui instruksinya pada bulan November 2019. Kemudian sebagian masyarakat Desa Wonoanti melalui Gapoktan Sedono Makmur melakukan pelatihan pembuatan pupuk organik dan pestisida nabati yang difasilitasi oleh pemerintah kabupaten melalui koordinator pertanian organik. Pelatihan ini juga dilakukan untuk meningkatkan pertanian organik untuk bisa berkembang dengan baik.

Untuk implementasi pupuk organik dan pestisida nabati ini dilakukan pada tanaman padi, kedelai, jagung, dan cabai. Kemudian dari tinjauan lapangan tanaman yang telah di aplikasikan menggunakan pupuk organik dan pestisida nabati bisa berkembang dengan hasil yang sama seperti pada saat masih menggunakan pupuk kimia (Subiastuti et al., 2022).

Dengan seiring berjalannya waktu kebutuhan pangan masyarakat semakin meningkat, namun tidak diiringi dengan luasnya lahan pertanian yang semakin hari semakin sempit dikarenakan pertumbuhan penduduk yang semakin tinggi. Lahan yang sempit masih dapat disiasati dengan melakukan usaha bercocok tanam yang dapat menghasilkan pangan yang sehat. Bercocok tanam yang dilakukan yaitu melalui teknologi hidroponik dengan memanfaatkan lahan yang terbatas (Nurhidayah et al., 2021; Roidah, 2014).

Hidroponik merupakan cara bercocok tanam dengan memanfaatkan media air sebagai media utama dengan mengkondisikan nutrisinya melalui sirkulasi air yang lebih menghemat air daripada menggunakan media tanam dengan tanah (Susilawati, 2019; Tallei et al., 2017; Yulina, 2019). Sehingga sistem bercocok tanam secara hidroponik dapat memanfaatkan lahan yang sempit. Oleh karena itu, perserta KSM-T UNISMA memiliki sebuah inovasi untuk bercocok tanam dengan menggunakan teknologi hidroponik guna membantu ketahanan pangan dan ekonomi masyarakat di masa pandemi.

\section{METODE}

Kegiatan pengabdian ini dilaksanakan pada bulan Agustus sampai dengan September 2021 di Desa Wonoanti kec. Gandusari Kab. Trenggalek. Metode yang dilaksanakan dalam pengabdian ini adalah pertama penyuluhan dengan memberikan penjelasan mengenai hal hal yang berkaitaan dengan teknik bercocok tanam hidroponik. Persiapan pelaksanaan program kerja berkoordinasi bersama dengan Koordinator Trenggalek Go Organik dan Ketua Gapoktan Sedono Makmur. Pelatihan ini dilaksanakan dengan penyampaian materi dan praktik secara langsung serta tanya jawab mengenai praktek pelaksanaan budidaya tanaman hidroponik sebagai upaya meningkatkan keterampilan warga dalam budidaya tanaman hidroponik. 
Penyuluhan dan pelatihan budidaya tanaman hidroponik di Desa Wonoanti dilaksanakan dikediaman Ketua Gapoktan dengan memanfaatkan limbah plastik dari botol bekas yang mudah didapat yang dilaksanakan selama satu hari dan diikuti oleh warga sekitar. Materi pelatihan dilakukan dengan metode pemaparan secara singkat dan tanya jawab kemudian dilanjutkan praktik budidaya tanaman hidroponik.

Adapun proses penyuluhan dan budidaya tanaman dengan metode hidroponik adalah sebagai berikut:

1. Melakukan sosialisasi tentang program pengabdian kepada masyarakat atau program kerja KSM-T UNISMA yang dilaksanakan di Desa Wonoanti.

2. Berkoordinasi dengan Ketua Gapoktan untuk teknik, waktu, dan pelaksanaan.

3. Melakukan pelatihan budidaya tanaman hidroponik secara singkat.

4. Melakukan praktek atau pelatihan cara budidaya tanaman hidroponik.

5. Melakukan evaluasi kegiatan.

Evaluasi kegiatan ini akan digunakan sebagai tolak ukur kedepan sehingga pembuatan atau pelatihan ini dapat dilaksanakan lebih baik.

\section{HASIL DAN PEMBAHASAN}

Program pengabdian pada masyarakat berupa penyuluhan dan pelatihan yang di ikuti oleh anggota kelompok tani di Desa Wonoanti, Kecamatan Gandusari, Kabupaten Trenggalek. Warga mendapatkan pengetahuan baru tentang cara menanam, dan media apa saja yang di perlukan untuk menanam tanaman hidroponik, sehingga lahan sempit dan kurang dimanfaatkan bisa digunakan untuk lahan bertani secara hidroponik.

Program Edukasi mengenai pelatihan budidayaa sayuran ini dilakukan selama Kandidat Sarjana Mengabdi (KSM). Program kerja ini sebagai upaya sebagai pelatihan di wilayah setempat. Program kerja pelatihan budidaya sayuran yang dilaksanakan yaitu Pelatihan Budidaya Sayuran Sawi Secara Hidroponik.

Pada pelatihan budidaya sayuran ini menggunakan biji sawi sebagai tanamannya. Media hidroponik yang digunakan adalah rocwoll. Cara pembuatannya pun cukup mudah, yaitu: (1) Menyiapkan baki yang telah diisi air, netpot, rockwoll yang telah dipotong dadu kecil - kecil, kain flanel dengan ukuran $\pm 10 \mathrm{~cm}$ x $3 \mathrm{~cm}$, dan biji sawi; (2) Mengambil netpot yang sudah disiapkan, kemudian kaitkan kain flanel di bagian bawah netpot. Hal ini bertujuan supaya air dalam pipa meresap ke dalam kain flanel agar biji sawi yang ditanam tetap terkena air; (3) Memasukkan rockwoll yang sudah dipotong dadu kecil - kecil ke dalam netpot; (4) Memasukkan netpot ke dalam pipa yang sudah dilubangi; (5) Memasukkan \pm 3 biji sawi pada masing - masing netpot; (6) Hidroponik sawi telah selesai, kemudian Meletakkan tanaman di daerah yang tidak terkena sinar matahari langsung.

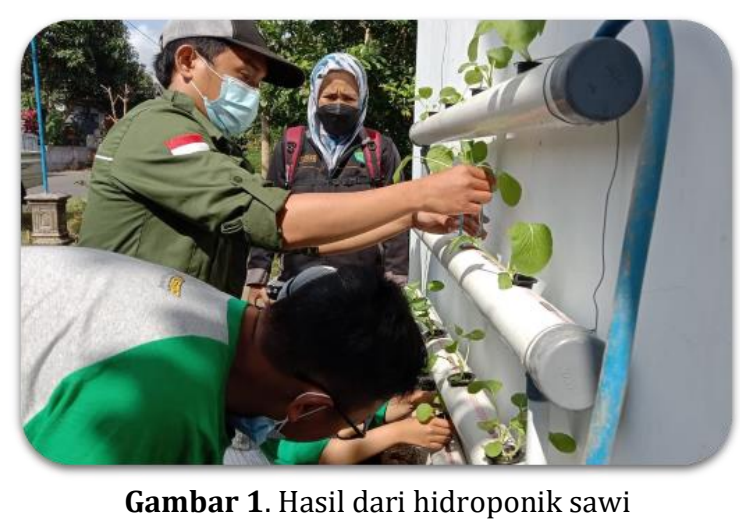

Gambar 1. Hasil dari hidroponik sawi 


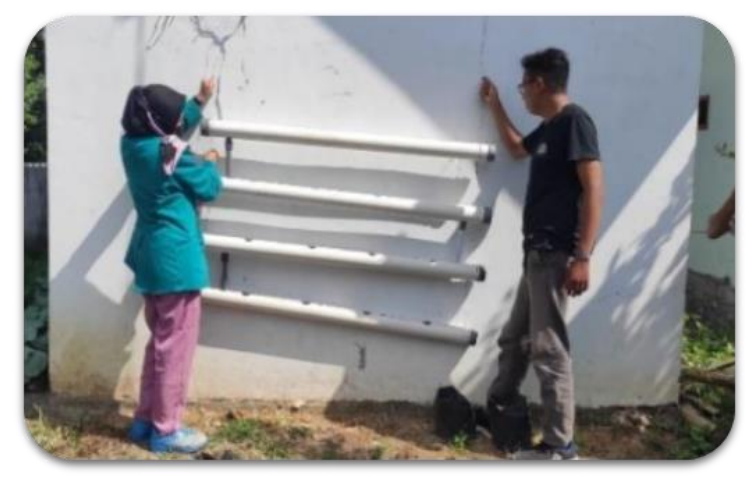

Gambar 2. Hidroponik bertingkat

Gambar 1 dan 2 menunjukkan salah satu kegiatan pelatihan yang dihadiri masyakarat sekitar. Pembuatan hidroponik memanfaatkan pipa sebagai media tanam dengan metode bertingkat dan aliran air dimulai dari tingkat paling atas, sehingga air dapat terus melewati semua tingkat dibawahnya. Selain itu, pupuk yang digunakan adalah pupuk organik dengan memanfaatkan limbah yang ada di rumah tangga. Edukasi pupuk organik sangat penting dilakukan untuk mengubah mindset masyarakat bahwa tidak hanya pupuk kimia yang bisa digunakan untuk bertanam namun pupuk organik dapat juga dimanfaatkan sebagai pupuk alternatif yang bersih dari peptisida dan murah dalam pembuatannya karena memanfaatkan limbah rumah tangga.

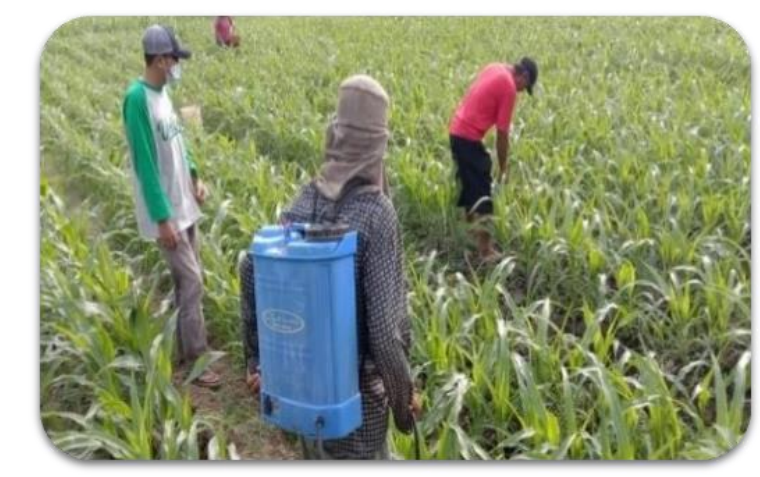

Gambar 3. Aplikasi pupuk organik pada tanaman jagung

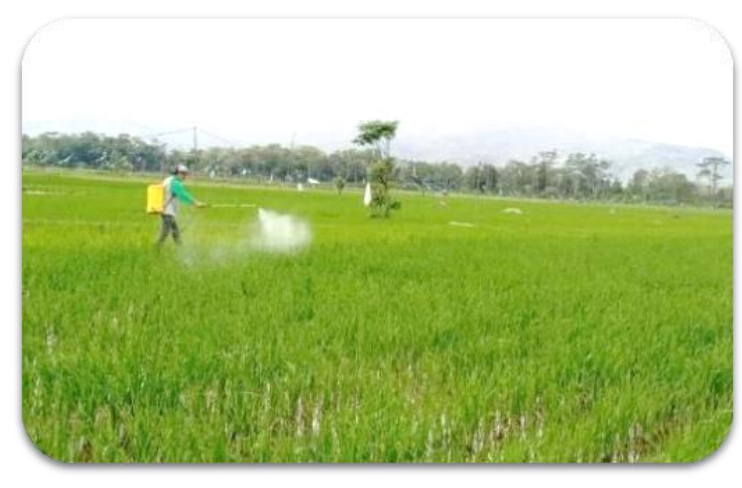

Gambar 4. Aplikasi pupuk organik pada tanaman padi

Edukasi penggunaan pupuk organik ditujukan pada kelompok tani di desa Wonoanti, Trenggalek (Gapoktan). Masyarakat kelompok tani tersebut sudah meningkatkan penggunaan pupuk organik secara bertahap, sehingga kelompok tani tersebut dapat mengedukasi kepada kelompok tani lainnya. Gambar 3 dan 4 menunjukkan beberapa anggota kelompok tani menyiramkan pupuk organik caik pada tanaman bahan pokok yaitu 
tanaman padi dan tanaman jagung. Dengan memanfaatkan limbah rumah tangga, penggunaan pupuk organik yang sebelumnya biaya pembelian pupuk organik cukup mahal bagi masyarakat desa Wonoanti menjadi lebih murah. Sehingga ketergantungan kelompok tani pada penggunaan pupuk bahan kimia menjadi berkurang secara bertahap.

\section{KESIMPULAN}

Dengan adanya pandemi COVID-19 seperti ini masih ada beberapa cara untuk meningkatkan perekonomian masyarakat. Salah satu cara yang dapat dilakukan yaitu dengan bercocok tanam menggunakan metode tanaman hidroponik. Hidroponik merupakan metode bercocok tanam tanpa menggunakan tanah, melainkan dengan menggunakan air. Metode hidroponik tidak membutuhkan lahan yang luas, sehingga masyarakat dapat mengoptimalkan pekarangan rumah mereka.

Selama kegiatan pengabdian terdapat indikator keberhasilan yang diperoleh adalah pembuatan alat untuk pembuatan pupuk pupuk organik baik dalam bentuk cair maupun padat yang berasal dari sisa limbah rumah tangga, dan pembuatan media tanam Hidroponik dari pipa dengan lahan yang terbatas. Pembuatan hidroponik cukup efektif dan mudah dipraktikkan oleh masyarakat sekitar, sehingga dengan keterbatasan lahan masyarakat tetap mampu menanam tanaman organic seperti sayuran dengan bahan pupuk organik. Kegiatan pelatihan dan edukasi pembuatan hidroponik dihadiri beberapa perwakilan masyarakat sehingga mereka siap menjadi kader untuk pelatihan hidroponik kepada masyarakat lain. Hal ini akan membuat program edukasi hidroponik dapat berjalan dengan mandiri oleh masyarakat tersebut.

Pembaca diharapkan mampu mengembangan teknik bertanam hidroponik secara maksimal. Hal tersebut diharapkan mampu meningkatkan produksi pangan sehat seperti sayuran dan buah-buahan yang mempunyai nilai ekonomis yang tinggi.

\section{UCAPAN TERIMA KASIH}

Terima kasih kepada pihak Desa Wonoanti, masyarakat sekitar serta kelompok tani "Gapoktan Sedono Makmur" yang telah membantu dalam pelaksanaan program KSM Tematik Unisma 2021 ini. Semoga bimbingan dan ilmu yang telah diberikan dan disampai dapat bermanfaat di kemudian hari.

\section{DAFTAR RUJUKAN}

Kurniasih, E. P. (2020). Dampak Pandemi Covid 19 Terhadap Penurunan Kesejahteraan Masyarakat Kota Pontianak. Prosiding Seminar Akademik Tahunan Ilmu Ekonomi Dan Studi Pembangunan 2020, 277-289.

Muhadiansyah, T. O., Setyono, \& Adimihardja, S. A. (2016). Efektivitas Pencampuran Pupuk Organik Cair Dalam Nutrisi Hidroponik pada Pertumbuhan dan Produksi Tanaman Selada ( Lactuca sativa L .). J. Agronida, 2(1), 37-46. https://doi.org/10.30997/jag.v2i1.749

Nurhidayah, Almisry, M. D., Wijiastuti, Y., Octavia, D., Safitri, D. N. K., Magfiroh, N., Hasan, M. H., Wulandari, S. P., Baihaki, A. W., Ighfirlana, Diondah, R. V., Latif, M. I. O. A., \& Husniyah, R. A. (2021). Pengembangan Sumber Daya Manusia dengan Pelatihan Tanaman melalui Media Hidroponik. Jurnal Pembelajaran Pemberdayaan Masyarakat (JP2M), 2(3), 199204. https://doi.org/10.33474/jp2m.v2i3.13375

Perdamaian, P. D., Puspita, A., \& Frida, N. (2020). Analisis Strategi Mempertahankan dan Mengembangkan Bisnis di Tengah Pandemi COVID-19 Serta Mengetahui Dampak Perkembangan dan Pertumbuhan COVID-19 di Indonesia. Jurnal Aktiva: Riset Akuntansi Dan Keuangan, 2(3), 28-36. https://doi.org/10.52005/aktiva.v2i3.61 
Roidah, I. S. (2014). Pemanfaatan Lahan Dengan Menggunakan Sistem Hidroponik. Jurnal $\begin{array}{llll}\text { Universitas } \quad \text { Tulungagung } & \text { 43-50. }\end{array}$ https://doi.org/10.36563/bonorowo.v1i2.14

Subiastuti, A. S., Daryono, B. S., \& Sukirno. (2022). Pemanfaatan pekarangan dan limbah rumah tangga untuk budidaya lele sebagai upaya memenuhi pangan keluarga selama pandemi covid-19. Jurnal Inovasi Hasil Pengabdian Masyarakat (JIPEMAS), 5(1), 1-10. https://doi.org/10.33474/jipemas.v5i1.11323

Susilawati. (2019). Dasar-Dasar Bertanam Secara Hidroponik. Universitas Sriwijaya.

Tallei, T., Rumengan, I. F. M., \& Adam, A. A. (2017). Hidroponik untuk Pemula. UNSRAT Press.

Vivi Gorahe, L., Waani, F., \& Tasik, F. (2021). Dampak Pendemi Covid-19 Terhadap Kesejahteraan Masyarakat di Desa Dalako Bambahene Kecamatan Tatoareng Kabupaten Kepulauan Sangihe. Jurnal Eksekutif, 1(1), 1-9. https://ejournal.unsrat.ac.id/index.php/jurnaleksekutif/article/view/34597

Yulina, H. (2019). Penyuluhan Budidaya Tanaman Hidroponik Di Desa Kalensari Kecamatan Widasari Kabupaten Indramayu. Abdi Wiralodra: Jurnal Pengabdian Kepada Masyarakat, 1(2), 112-124. https://doi.org/10.31943/abdi.v1i2.10 